\title{
A millimetric ruler for Lester Jones tube placement in conjunctivodacryocystorhinostomy
}

This article was published in the following Dove Press journal:

Clinical Ophthalmology

25 August 2015

Number of times this article has been viewed

\section{Rodolfo Luis Vigo \\ Tomás Ortiz-Basso \\ María Natalia Vilas \\ Jorge Prémoli}

Ophthalmology Department, Hospital Italiano de Buenos Aires, Buenos

Aires, Argentina
Correspondence: Rodolfo Luis Vigo Ophthalmology Department, Hospital Italiano de Buenos Aires 450 Gascon Street (CI I99ABD), Buenos Aires, Argentina

Tel +54 II 49590200

Email rodolfovigo@gmail.com
Purpose: To describe the use of a ruler to increase the accuracy and customization of Lester Jones tube placement.

Materials and methods: This was a review of 92 patients who underwent minimally invasive conjunctivodacryocystorhinostomy using this instrument.

Results: The success rate was $100 \%$, with an average operating time of 15 minutes. In nine patients, late migration of the Jones tube into the nasal cavity required a secondary intervention, with successful Jones tube repositioning. In five cases, obstruction of the tube opening was caused by conjunctival overgrowth.

Conclusion: The millimetric ruler engraved in the sleeve of the trocar allows measuring and placing a personalized tube for each patient.

Keywords: lacrimal apparatus, lacrimal apparatus diseases, lacrimal duct obstruction, dacryocystorhinostomy, surgical instruments

\section{Introduction}

Conjunctivodacryocystorhinostomy (CDCR) with a Jones tube is the chosen technique to treat higher lacrimal duct obstructions. ${ }^{1,2}$ However, the complications associated with it and the difficulty of the technique may turn out to be frustrating. ${ }^{3,4}$ In this study, we present a technique that facilitates the insertion of the Jones tube with excellent results.

\section{Materials and methods}

This study adhered to the principles outlined in the Declaration of Helsinki, and was approved by the Institutional Review Board - IRB 00003580. In this retrospective study, the charts of 92 patients who underwent CDCR as a primary or revision surgery at Hospital Italiano de Buenos Aires between April 2008 and April 2014 and had follow-up for more than 6 months were reviewed.

Patients comprised $60 \%$ males $(n=56)$ and $40 \%$ females $(n=36)$. The mean age was 51 years, and the mean follow-up period was 30 months (range: 18-60 months). A variety of Jones tubes ranging from 19 to $23 \mathrm{~mm}$ in length were used. The exclusion criteria were lacrimal duct obstruction due to tumor, sinusitis, and bone diseases.

A video endoscope (Tricam SL; KARL STORZ GmbH and Co KG, Tuttlingen, Germany) was introduced into the middle nasal cavity for visualization and electrocauterization. The inferior third of the caruncle was excised. The trocar (Figure 1) was inserted from the semilunar directed to the middle meatus through the thin lacrimal bone (Figure 2). Once the trocar was in a satisfactory position, the central wire was removed, and the sleeve allowed the direct insertion of a guide rod. Before removing it, the millimetric ruler (Figure 3), which was engraved in the sleeve, was checked. In this way, 


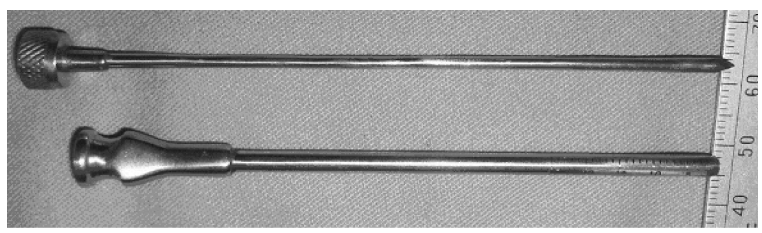

Figure I Trocar for Jones tube placement, with a millimetric ruler engraved.

we were able to find a personalized tube for each patient. After the trocar sleeve was removed, a Pyrex Lester Jones tube was inserted down the guide rod. The proximal end of the tube was secured in position at the medial canthus with a 6.0 nylon suture, which was removed 20 days after the surgery. See the full video of the surgery using the millimetric ruler.

\section{Results}

The success rate was $85 \%$. The other $15 \%$ presented mild complications, which were solved with a second intervention. The surgeries were performed in an average time of 15 minutes.

Migration of the tube was the most frequent complication. In nine cases, the tube migrated into the nose, with successful repositioning. Obstruction of the Jones tube by the conjunctiva was the second-most frequent complication, and five cases needed excision of the conjunctiva.

\section{Discussion}

Lacrimal canalicular bypass tract surgery, first described by Jones, is indicated for epiphora secondary to obstruction at the level of the canaliculi, failed DCR, and lacrimal pump dysfunction. ${ }^{1-3,5}$ Unfortunately, this procedure is associated with multiple complications; therefore, it requires long-term follow-up. ${ }^{6-8}$

A minimally invasive approach with no skin incision has been described..$^{9}{ }^{10}$ However, placement of a Jones glass tube can be difficult with this technique. The distal end is

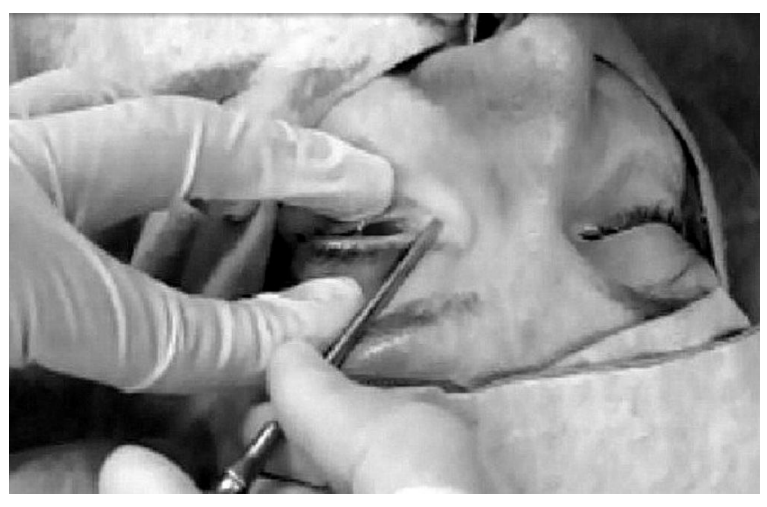

Figure 2 Trocar inserted through the lacrimal bone.

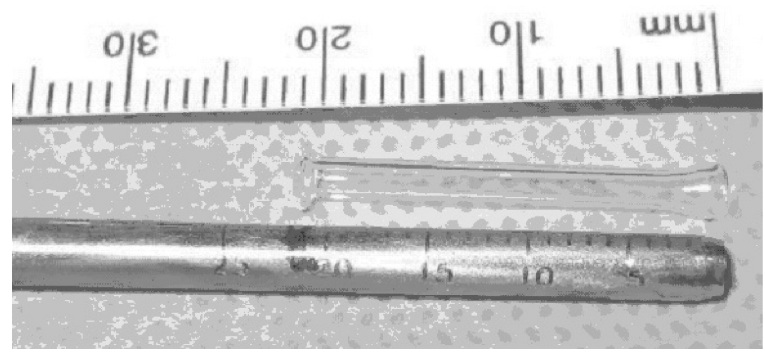

Figure 3 Measurement by Jones tube for a personalized placement.

wider than the tube's outer diameter, so soft tissue within the tunnel is often drawn in front of the tube, complicating placement. Moreover, the length of the tube cannot be calculated beforehand, and its choice respresent a challenge for the surgeon. Some authors identify the latter as a major reason of failure. ${ }^{11}$

The use of a steel double-component trocar guide by endoscopic view maintains the desired tract for positioning the tube; this reduces the operating time and the risk of malpositioning. We add an advantage to the trocar with a millimetric ruler, which is engraved in the sleeve to measure the tube for every patient.

With this technique, the placement of the tube is easier and quicker, and not many changes are necessary to choose the most appropriate one. The limitations of our study are as follows: it is retrospective, there was no control group, and longer follow-up may be needed to determine long-term complications.

\section{Conclusion}

This millimetric ruler engraved on the trocar allows measuring and placing a personalized tube for each patient. It also eases the Jones tube placement with endoscopic control, maintaining the desired tract for positioning the tube. This reduces the operating time and the risk of malposition.

\section{Disclosure}

The authors report no conflicts of interest in this work.

\section{References}

1. Jones LT. Conjunctivodacryocystorhinostomy. Am J Ophthalmol. 1965; 59:773-783.

2. Doucet TW, Hurwitz JJ. Canaliculodacryocystorhinostomy in the management of unsuccessful lacrimal surgery. Arch Ophthalmol. 1982; 100:619-621.

3. Welham RA, Guthoff R. The Lester-Jones tube: a 15-year follow-up. Graefes Arch Clin Exp Ophthalmol. 1985;223:106-108.

4. Vicinanzo MG, Allamneni C, Compton CJ, Long JA, Nabavi CB. The prevalence of air regurgitation and its consequences after conjunctivodacryocystorhinostomy and dacryocystorhinostomy in continuous positive airway pressure patients. Ophthal Plast Reconstr Surg. 2015;31: 269-271. 
5. Rose GE, Welham RA. Jones' lacrimal canalicular bypass tubes: twenty-five years' experience. Eye (Lond). 1991;5:13-19.

6. Sendul SY, Cagatay HH, Dirim B, et al. Comparison of Medpor coated tear drainage tube versus silicon tear drainage tube in conjunctivodacryocystorhinostomy: problems and solutions. ScientificWorldJournal. 2014;2014:164834.

7. Sekhar GC, Dortzbach RK, Gonnering RS, Lemke BN. Problems associated with conjunctivodacryocystorhinostomy. Am J Ophthalmol. 1991; 112:502-506.

8. Steinsapir KD, Glatt HJ, Putterman AM. A 16-year study of conjunctival dacryocystorhinostomy. Am J Ophthalmol. 1990;109:387-393.
9. Devoto MH, Bernardini FP, de Conciliis C. Minimally invasive conjunctivodacryocystorhinostomy with Jones tube. Ophthal Plast Reconstr Surg. 2006;22:253-255.

10. Komínek P, Cervenka S. Conjunctivodacryocystorhinostomy tube placement with a urologic catheter. Ophthal Plast Reconstr Surg. 2005;21: 235-236.

11. Chang M, Lee H, Park M, Baek S. Long-term outcomes of endoscopic endonasal conjunctivodacryocystorhinostomy with Jones tube placement: a thirteen-year experience. J Craniomaxillofac Surg. 2015;43:7-10.
Clinical Ophthalmology

\section{Publish your work in this journal}

Clinical Ophthalmology is an international, peer-reviewed journal covering all subspecialties within ophthalmology. Key topics include: Optometry; Visual science; Pharmacology and drug therapy in eye diseases; Basic Sciences; Primary and Secondary eye care; Patien Safety and Quality of Care Improvements. This journal is indexed on

Submit your manuscript here: http://www.dovepress.com/clinical-ophthalmology-journal

\section{Dovepress}

PubMed Central and CAS, and is the official journal of The Society of Clinical Ophthalmology (SCO). The manuscript management system is completely online and includes a very quick and fair peer-review system, which is all easy to use. Visit http://www.dovepress.com/ testimonials.php to read real quotes from published authors. 